\title{
BORGES'S POE: THE INFLUENCE AND REINVENTION OF EDGAR ALLAN POE IN SPANISH AMERICA
}

\section{EL POE DE BORGES: LA INFLUENCIA Y LA REINVENCIÓN DE EDGAR ALLAN POE EN HISPANOAMÉRICA}

\author{
Emron Esplin \\ The New Southern Studies, University of Georgia Press, 2016, pp. 238 \\ ISBN: 9780820349053 \\ Margarita Rigal Aragón \\ Universidad de Castilla-La Mancha, España \\ Margarita.rigal@uclm.es
}

Recibido: 23 de junio de 2021

Aceptado: 29 de agosto de 2021

In 1934, John Eugene Englekirk's Edgar Allan Poe in Hispanic Literature was published. Englekirk's work approached some Spanish authors who showed, according to him, the influence of Poe in their works; however, he focused mainly on South American writers. Since then, multiple researchers have worked on the relationship between Spanish speaking authors and this master of story telling. That is the case of the extensive bibliographical work prepared by Rafael Heliodoro Valle (1950) and by Hensley Woodbridge (1969). Several of them, before Emron Esplin, concentrated mainly on the bond between Borges and Poe. This was the case, for instance, of Maurice J. Bennet's 1983 essay, "The Detective Fiction of Poe and Borges," which presented one of the earliest comparative interpretations of Borges's legendary story "La muerte y la brújula" ["Death and the Compass"] together with Poe's Dupin trilogy. A decade later, in 1994, a milestone on the matter appeared: an interdisciplinary voyage through Poe's and Borges's analytic minds, John T. Irwin's The Mystery to a Solution: Poe, Borges, and the Analytic Detective Story. Right before the turn of the century, Gabriella Tissera revisited, again, this link in Lois Davis Vines's 1999 Poe Abroad.

Since his 2006 publication of "From Poetic Genius to Master of Short Fiction: Edgar Allan Poe's Reception and Influence in Spanish America from the Beginnings through the Boom", Emron Esplin seemed to have been preparing the ground for his Borges's Poe. In 2010, “Reading and Re-Reading: Jorge Luis Borges' Literary Criticism on Edgar Allan Poe" started to mark the difference between Esplin's studies on Poe \& 
Artículo. Margarita Rigal Aragón. "Borges's Poe: The influence and reinvention of Edgar Allan Poe in Spanish America"

Borges and those of his predecessors. If the several critics mentioned above had contrasted Borges's and Poe's oeuvres underlining the prominence of each writer, Esplin was centering on treating Poe as source and Borges as receptacle. He continued deepening into this field with his 2013 "Borges's Philosophy of Poe's Composition." In this essay, he explored several of Borges's critical approaches to Poe focusing on the regional context of these interpretations; he was also examining the influence of Borges's considerations, something that was not present in most of the previous comparative readings of these two authors.

Borges's Poe: The Influence and Reinvention of Edgar Allan Poe in Spanish America is, in consequence, the result of careful and meticulous research that evolved over a decade. The book is divided into three perfectly balanced parts in which Esplin investigates the different forms in which Borges interpreted Poe. Borges achieved this through his profound knowledge of Poe's literary criticism, short stories, Pym, and Eureka. But he also engaged with Poe in a very personal and much deeper way; and he did so thanks to his own essays on Poe, his own fiction (in which Poe was often present), and his curious "translations" of Poe's "The Facts in the Case of M. Valdermar," "The Purloined Letter," and some fragments of Pym.

In "Part 1" Esplin revisits his own 2010 and 2013 essays and scrutinizes Borges' literary criticism on Edgar Allan Poe. As Esplin puts forward (2016: 14), Borges discussed Poe in over 130 articles, essays, and prologues, from 1923 to the year of his death, $1986^{1}$; he also referred to Poe in interviews and collaborative works of literary criticism throughout his life. Esplin uses these facts to demonstrate Poe's perennial influence on Borges; he also reviews Borges's reactions to "The Philosophy of Composition" and explains how Borges managed to confront Rubén Dario's and los modernistas' appreciation of Poe as a genius and a poet-prophet ${ }^{2}$. Thanks to Borges, Poe started to be read and comprehended in Spanish America as a writer of short fiction, and as the inventor of the detective genre, too (Esplin 2016: 55). For instance, in his 1935 essay "La genesis de 'El cuervo' de Poe," Borges exposed that the analytic and creative mind of Dupin matches the analytic and creative conflicts present in "The Raven" and in "The Philosophy of Composition." In the final lines of this section, Esplin also explores Borges's very personal

\footnotetext{
${ }^{1}$ See, for instance, Borges, J.L. (1987).

${ }^{2}$ See Dario, R. "Los raros" (1893). Obras completas. (1950).
} 
interpretation of the final part of Pym, empathizing — once again — the analytic in Poe's prose.

"Part 2" of Borges's Poe is even more fascinating. Here Esplin displays his profound knowledge on translation studies (and not only on Poe and Borges) ${ }^{3}$. Esplin refers the reader back to James Holmes's and Itamar Even-Zohar's theories ${ }^{4}$, and to Borges' own thoughts on translation, as revealed mainly in two of his works: "Pierre Menard, autor del Quijote" (1939) to make the reader of his book realize that for Borges "both originals and translations, both source texts and target texts, should be read in their own right as texts in conversation with, but not subservient to, one another" (Esplin, 2016: 70). In this light, Esplin first contrasts and evaluates the two fragments of Pym translated by Borges bearing Poe's original in mind, and he explains how, for Borges, Pym was not an adventure novel but a piece of detective fiction. Afterwards, Esplin masterfully helps those who have approached the 1943 Bioy Casares and Borges collaborative translations of "M. Valdemar" and "Purloined" to realize that Bioy Casares and Borges's intention was not to provide literal translations of these texts, but to create their own artistic versions of both ${ }^{7}$.

If the four chapters that conform the two first sections of Borges's Poe open new and very interesting lines in the research concerning these two authors, "Part 3," entitled "Rewriting Poe: Jorge Luis Borges's Poe-Influenced and Poe-Influencing Short Fiction," offers an amazing powerful evidence of Esplin's comprehension of both authors ${ }^{8}$. Irwin's 1994 The Mystery to a Solution had already put forward Borges's responses to the Dupin trilogy; here, in Chapter 5 ("Buried Connections") Esplin goes further by, meticulously, uncovering the hidden relationship between Poe's "Loss of Breath" and Borges's "Funes el

\footnotetext{
${ }^{3}$ See, Esplin, E. and Vale de Gato. Eds. (2014)

${ }^{4}$ See Even-Zohar, I. (2000: 192-197). Also see, in the same compilation, Holmes, J.S. "The Name and Nature of Translation Studies" (172-185).

${ }^{5}$ See Borges, J.L. (2007: 457-459).

${ }^{6}$ See Borges, J.L. (2007: 130-133).

${ }^{7}$ See Borges, J.L, and Bioy Casares, A. (1997: 23-38). See, too, Borges, J.L, and Bioy Casares, A. (1971: 2328).

${ }^{8}$ I have read intriguing opinions contrary to mine. For instance, Whitney S. May (2016: 196-198), in her review of Borges's Poe, asserts: "While the book begins with the claim that Poe influences Borges, who later influences Poe's image in Spanish America, it detours into a discussion of Borges's influence on Poe's themes by its final chapters. The result is an argument that seems to run out of steam as it progresses" (198). However, according to my understanding, Esplin does not claim that Borges has an influence on Poe's themes, but that the interpretation Borges makes of Poe's themes influences the contemporary reader of Poe if that reader has read Borges.
} 
Artículo. Margarita Rigal Aragón. "Borges's Poe: The influence and reinvention of Edgar Allan Poe in Spanish America"

memorioso" and "El Aelph." With an impeccable scientific methodology Esplin proves that “reading 'Loss of Breath,' 'Funes el memorioso,' and 'El Aelph,' side by side, demonstrates Borges's knowledge of and reaction to "Loss of Breath" rather than confluence or casual intertextuality" (Esplin, 2016, 116). One of Esplin's greatest contributions in this chapter, and in the following one (Chapter 6: "Supernatural Revenge"), is the deepest knowledge he shows of Poe's oeuvre. Esplin digs deeper than many scholars and visits (or revisits) the precise Poe or Borges tale/story/document/manuscript he needs to use: the longer, more complete version of "Loss of Breath," as published in Tales of the Grotesque and Arabesque (1840) ${ }^{9}$ and the first manuscript of "El Aleph," kept in the Spanish Biblioteca Nacional (Madrid). The latter helps Esplin to build his very novel and noteworthy theory of considering "Metzengerstein" and "The Black Cat"-along with "El Aleph"- as tales of supernatural revenge.

Borges's Poe closes with an enlightening "Epilogue" that rounds the book and takes the reader back to the Introduction. (As Borges, himself, used to do in his own stories.) Esplin pays special attention in these final pages to the Poe-Cortázar-Borges relationship. Esplin is, as well proven by his chapter in Translated Poe (2014: 251-260), an authority on Cortázar's role in the diffusion of Poe's prose in the Spanish speaking world. This makes me hope for a Cortazár's Poe as well grounded as this Borges's Poe ${ }^{10}$.

\section{REFERENCES}

Bennett, M. J. "The Detective Fiction of Poe and Borges." Comparative Literature, Vol. 35, No. 3, 1983, pp. 262-275.

Borges, J.L. "Sobre Edgar Allan Poe", published posthumously in Diálogos últimos. Sudamericana, 1987, pp. 189-194.

---. Obras completas, vol. 1. Emecé, 2007.

Borges, J.L, and A. Bioy Casares, translators. "La verdad sobre el caso de M. Valdemar" Antología de la literatura fantástica. E. A. Poe. Sudamericana, 1971, pp. 23-28.

--- "La carta robada". Los mejores cuentos policiales. Emecé, 1997, pp. 23-38.

Dario, R. "Los raros" [1893]. Obras completas, vol. 2. Afrodisio Aguado, 1950, pp. 245518.

Englekirk, J. E. Edgar Allan Poe in Hispanic Literature. New York, Instituto de las Españas en los Estados Unidos, 1934.

\footnotetext{
${ }^{9} \mathrm{https} / / / \mathrm{www}$. eapoe.org/works/editions/tgavolI.htm

${ }^{10}$ Indeed, Eplin's on-going research on Poe and Spanish America points in this line; for instance, in his " 'Un muerto vivo': Poe and Argentina" (2018: 321-341) and in his "Poe and His Global Advocates" (2019: 597617), Esplin continues to deepen on the Poe-Quiroga-Borges-Cortázar liaison.
} 
Esplin, E. "From Poetic Genius to Master of Short Fiction: Edgar Allan Poe's Reception and Influence in Spanish America from the Beginnings through the Boom." Resources for American Literary Study, vol. 31, 2006, pp. 31-54.

---. "Reading and Re-Reading: Jorge Luis Borges' Literary Criticism on Edgar Allan Poe. Comparative American Studies. An International Journal, vol. 8, no. 4, 2010, pp. 247-266.

---. “Borges's Philosophy of Poe's Composition." Comparative Literature Studies, vol. 50, no. 3, 2013, pp. 458-489.

---. "'William Wilson' as a Microcosm of Julio Cortázar's Poe Translations: Horror in the Doubling of the Human Will'. Esplin and Vale de Gato, pp. 251-260.

---. “Un muerto vivo': Poe and Argentina." Poe and Place, edited by P. E. Phillips. Ed. Palgrave Macmillan, 2018, pp. 321-341

---. (2019). "Poe and His Global Advocates." The Oxford Handbook of Edgar Allan Poe. edited by G. Kennedy \& Scott Peeples. Oxford University Press, pp. 597-617.

Esplin, E. and M. Vale de Gato, editors. Translated Poe. Lehigh University Press, 2014.

Even-Zohar, I. "The Position of Translated Literature within the Literary Polysystem." Venuti, pp. 192-197.

Heliodoro Valle, Rafael. "Fichas para la bibliografía de Poe en Hispanoamérica." Revista hispanoamericana, no. 16, 1950, pp. 199-214.

Holmes, J.S. “The Name and Nature of Translation Studies”. Venuti, pp. 172-185.

Irwin, J. T. The Mystery to a Solution: Poe, Borges, and the Analytic Detective Story. The Johns Hopkins U. P, 1994.

May, Whitney S. "Review of Borges's Poe." The Edgar Allan Poe Review, Volume 17, Number 2, 2016, pp. 196-198

Tissera, G. "Jorge Luis Borges." Poe Abroad: Influence, Reputation, Affinitties. L. D. Vines, editor. U. of Iowa P., 1999, pp. 221-226.

Venuti, Lawrence, editor. The Translation Studies Reader. Routledge, 2000.

Woodbridge, H. C. "Poe in Spanish America: A Bibliographical Suplement. Poe News Letter, No. 2, 1969, pp. 18-19. 